\title{
Strategies for Managing Teachers with HIV/AIDS in South African Schools
}

\author{
G.M. Steyn and B.J. Mfusi
}

\author{
Department of Educational Leadership and Management, University of South Africa, \\ PO Box 392, Pretoria 0003, South Africa \\ Cell: +2782 886 7468, Fax: +2712664 6802 or +27 124294922 , \\ E-mail: steyngm1@unisa.ac.za
}

KEYWORDS Strategies. School Principals. Teachers. Education Sector. Management. HIV/AIDS

\begin{abstract}
HIV/AIDS poses a severe threat to the quality of schooling in South Africa. School principals may play a key role in managing educators with (Human Immunodeficiency Virus/ Acquired Immunodeficiency Syndrome (HIV/AIDS). This article reports on part of the investigation done for a Master's dissertation. Its research aim was to identify the needs and challenges which school principals face in managing educators with HIV/AIDS. The purpose of this article was to identify strategies for the management of educators infected with HIV/AIDS in schools. In order to obtain a better understanding of the problem, a qualitative research strategy, in particular an interpretative approach, was selected as the most appropriate research design. Data collection was done by means of individual interviews with school principals and focus group interviews with teachers, while the data analysis was done using Colaizzi's approach. The findings reveal that there are certain measures which could be applied to manage educators with HIV/AIDS. The article concludes by making recommendations for principals, the Department of Education and teachers.
\end{abstract}

\section{INTRODUCTION}

HIV/AIDS remains one of the many challenges facing South Africa today (Campbell and Gibbs 2008; articles in The Mercury [The stigma that can kill 2008] and The Witness [Changing habits: The President and HIV prevention 2010:10] and it presents a unique challenge to education and schools (Coombe 2002). McLean and Hiles (2005) and Sawers and Stillwaggon (2010) state that no deadly disease spreads as rapidly or has had such a huge impact on schooling as HIV/AIDS. Considering the status of HIV/ AIDS in South Africa, principals have a responsibility to accept the challenge to manage HIV/ AIDS with the same devotion as other areas in the school (Calitz et al. 2002; Rajagopaul 2008). School principals constitute an important component of the education sector and are uniquely placed as managers to combat HIV/AIDS (Rayners 2007; Rajagopaul 2008). They are confronted with increasing numbers of HIV positive teachers on a daily basis (Rayners 2007; Firnhaber and Michelow 2009). Although the prevalence of HIV infected people dropped in South Africa from 21.5 percent in 2007 to 10.7 percent in 2008, in KwaZulu-Natal it increased to $37.4 \%$ during the same period (HIV and AIDS Statistics for South Africa 2010).

Research on HIV/AIDS has predominantly focused on different strategies to bring the dis- ease under control and find a cure. Many drugs have been tested, but none of these have been successful in getting rid of the virus or in stopping the virus from damaging the immune system (UNAIDS 2006). These facts have led Calitz et al. (2002) to believe that the only way to avoid the risk of infection is to avoid exposure. Moreover, people need to be educated to change their sexual behaviour, which is the best way to reduce the spread of the virus (Coombe 2002; UNAIDS 2006; Delport et al. 2011). According to Badcock-Walters et al. (2004), cognitive and literacy skills are required to make informed choices on HIV/AIDS. It is therefore evident that there is a wide acceptance of the key role of education as the only effective available "vaccine" against HIV/AIDS (Rajagopaul 2008; Kelly 2008). This was confirmed by Professor Alan Whiteside (HIV treatment without prevention is like mopping the floor while the tap is running" (The Witness 12 February 2010).

Several strategies to combat HIV/AIDS have been put in place by the South African Government since 1994. The Department of Education has also played a major role by introducing certain mechanisms to prevent HIV/AIDS transmission in schools. These include the National policy on HIV/AIDS for learners, students and educators (Department of Education 2002: 4; Govender 2003:15; Simbayi et al. 2005: 31), the Life skills programme (Buchel 2006: 60; Coombe 
in Mkhonto 2005: 5; Visser 2005: 206; Republic of South Africa 2007: 44), the HIV/AIDS emergency guidelines for educators (Department of Education 2000:5-13; Govender 2003: 16); HIV/ AIDS in the workplace (Coombe 2000: 39) and the HIV/AIDS impact assessment in the education sector in South Africa (Coombe 2000: 40).

According to Rajagopaul (2008: 7) there is "a dire need for research on the role to be played by school leaders in limiting the impact of HIV and AIDS" since the majority of school leadership studies do not address the HIV/AIDS pandemic in schools. Against this background, the article reports on part of the investigation done for a Master's dissertation (Mfusi 2011). The broad research aim of this study was to identify needs and challenges facing school principals in managing educators with HIV/AIDS and to provide school principals with in-depth information on how to manage educators with HIV/ AIDS. This article attempted to investigate the following research question: Which strategies can be put in place to manage teachers with HIV/ AIDS in South African schools?

\section{Theoretical Framework}

The theoretical framework underpinning this study includes the adult learning theory, in particular the transformational learning theory which concerns the manner in which adults make meaning of a particular phenomenon (Anfare and Mertz 2006; Erichson 2007). The transformative learning theory essentially deals with learning and changes in people's lives and their understanding of themselves in their contexts and the world around them (Erichson 2007). "It involves participation in constructive discourse to use the experience of others to assess reasons justifying these assumptions, and making an action decision based on the resulting insight" (Erichson 2007: 1). The following assumptions (Anfare and Mentz 2006) applied to the study:

- The life experiences of people in combination with both their individual and social contexts in which these experiences occur, provide the possibility for learning and development.

- The "desired direction of development" is geared towards obtaining responses which would help in identifying suitable strategies to manage a particular problem, in this case the management of educators with HIV/ AIDS.
According to Mezirow's transformational model it is critical to examine these underlying assumptions and to engage in "a special form of dialogue" with participants for the purpose of "reviewing the evidence and arguments for and against the problematic assertion to arrive at a consensus" (Mezirow 1995: 53).

Considering the above, the development of creative strategies is paramount in seeking a comprehensive plan to manage educators infected with HIV/AIDS more effectively.

\section{RESEARCH METHODOLOGY}

This study reported on qualitative data (Delport et al. 2011; Creswell 2008; Mouton 2009; Neutens and Rubinson 2010), the qualitative research approach deemed as most appropriate to identify the strategies to manage the HIV/AIDS pandemic among teachers. The sample selected was guided by the study's research question, which also guided the data collection methods (Anfare and Mentz 2006). Data were collected at the site where participants (school principals and teachers) experienced the issue or problem around HIV/AIDS (Creswell 2007). An interpretivist approach was used to understand, describe and interpret the experiences of participants in order to identify strategies to manage educators with HIV/AIDS (Creswell 2007).

Purposeful sampling was used, in which information-rich participants were identified. Six experienced primary school principals and four secondary school principals in a particular circuit in KwaZulu-Natal were interviewed. Their teaching experience ranged from 15 to 30 years and their management experience from 10 to 25 years. In addition ten information-rich teachers were selected, one from each of the ten schools for focus group interviews. The teaching experience of these teachers ranged from 5 to 15 years, and since they were engaged in Life Orientation subjects and/or HIV/AIDS awareness programmes, they were familiar with the research topic.

All interviews with participants were based on an interview schedule, which served as a guide to collect data. Interviews were supported by field notes taken while being conducted. Interviews with principals were conducted in their offices whilst those with focus group participants took place at pre-arranged venues at the individual schools since the latter constituted 
their natural setting and ensured privacy. This arrangement allowed participants to express their views freely on the issue of HIV/AIDS and its management.

The interviews were tape-recorded and transcribed verbatim after permission had been granted by the participants. All ethical measures, which included informed consent (McMillan and Schumacher 2010), guarding against manipulating participants (Bogdan and Biklen 2007), confidentiality and anonymity (Neutens and Rubinson 2010) were applied during the data collection process. Since this study forms part of another study addressing problems experienced in managing teachers with HIV/AIDS, this study focussed particularly on the mentioned main question: Which strategies can be put in place to manage educators with HIV/AIDS?

The data analysis was done using Colaizzi's approach, which involved collected data being systematically investigated and arranged in terms of strategies that principals could devise to manage educators with HIV/AIDS (Creswell 2007). Using this approach, all written transcripts and field notes were read several times to ensure that the experiences of participants (school principals) concerning strategies that could be used to manage educators with HIV/AIDS (McMillan and Schumacher 2010) were described and interpreted correctly. In order to restrict bias and ensure trustworthiness, a participant's verbatim accounts, low-inference descriptors, participants' reviews and mechanically recorded data were considered ( McMillan and Schumacher 2010).

\section{RESEARCH FINDINGS}

From the findings it became clear that HIV/ AIDS had a huge impact on the quality of education and drastically influenced the progress of the schools. One principal explained:

We experience problems such as persistent absenteeism by sick educators, shortage of substitute educators, anger and aggression displayed by these educators, disruption of the curriculum, stigma and discrimination... HIVI AIDS is really affecting the progress of the school. Once an educator has been infected with HIV/AIDS, the whole school will be affected. Teachers are unable to perform their duties and learners are unable to attend their lessons because of the impact of HIVIAIDS... I personally feel that schools do not have sufficient resources to adequately implement all the provisions necessary for reducing the impact of HIV/AIDS.

To curb this HIV/AIDS pandemic, schools need to identify strategies to address this issue. The mechanisms which schools have already put in place to manage educators with HIV/AIDS revealed a number of categories: Combining grades of teachers; utilising substitute teachers, surplus teachers and retired and resigned teachers; developing appropriate policies on HIV/AIDS and sexual abuse of learners and codes of conduct; strategies relating to sexual abuse of learners; strengthening schools as centres of care and support; and strategies dealing with the disclosure of information, confidentiality and dismissal of teachers. A literature control was done throughout the discussion of data to interpret the findings.

\section{Combining Grades of Teachers}

Participants all reported that they combined different grades in one class to cover the work planned by the sick educator. One principal expressed her frustration around combining grades as follows: "Combining grades leads to higher stress levels for educators and they eventually become demoralised". Another principal warned against too much emphasis on combining grades in schools. She argued:

Another problem we usually experience concerning sick educators is that their work is normally given to their colleagues, who become overloaded and experience high stress levels. Under these circumstances, effective teaching and learning cannot take place.

This view was supported by another participant: "Once educators are overloaded they are not going to provide quality teaching". This is validated by Van Wyk and Lemmer (2007), who point out that colleagues often have to stand in for absent teachers and are therefore forced to take on double classes. As a solution one principal suggested that "principals must first explain the problem of infected and affected educators so that educators can take their duty load willingly, otherwise educators will be reluctant to take extra load". Furthermore, Theron et al. (2008) confirm that many teachers who want to quit the teaching profession cite the challenges of teaching in an HIV altered reality as one of the main factors motivating their attrition. The 
appointment of substitute teachers may provide an alternative to the combination of certain grades, which puts an extra burden on the already heavy workload of teachers.

\section{Utilising Substitute Teachers, Surplus Teachers and Retired and Resigned Teachers}

There was consent among participants that schools used different means to address the absenteeism of HIV/AIDS teachers. HIV/AIDS infected teachers were often replaced by substitute teachers and surplus teachers. As regards substitute teachers, principals indicated that this measure posed a predicament, as they had to provide for substitute teachers in advance to address the problem of persistent absenteeism by HIV positive educators. One principal explained the predicament as follows:

When educators are ill, we do not always get substitute educators. Even when we happen to get them, there are no professionally qualified educators these days. Sometimes educators are forced to teach the subjects that they do not know because the teacher who knows the subject is sick.

The majority of principals pointed out that they usually kept a leave register in their respective schools to monitor the absences of infected educators as evidence to show the Department of Education how their schools have been affected by the HIV/AIDS pandemic. Some participants suggested that sick educators be encouraged to apply for long sick leave in order for schools to qualify for substitute educators. The participants also felt that the Department of Education should train people to serve as substitute educators, otherwise "a lot of time will be spent trying to find a replacement", as one principal put it. The principals revealed that they always encouraged their staff members to apply for Medical Aid in order to ease the burden of sick teachers needing medical treatment.

The literature also endorses the fact that timely appointment of substitute educators is vital, that the Department of Education should budget for the appointment of substitute educators, and that principals should have a list of emergency relief teachers at all times (Calitz et al. 2002; Buchel 2006).

Most participants reported that certain schools did not their own have surplus teachers. Once a school experienced the problem of absenteeism, participants mentioned that principals made a point of networking with the principals of schools with surplus teachers to utilise their services. A principal explained:

We also make use of surplus educators from other schools, but the problem is that those educators are reluctant to be placed where there is a shortage of educators. I think the Department of Education must formulate a policy to deal with surplus educators.

According to the majority of the participants, utilising surplus teachers on its own would not entirely address the problem of persistent absenteeism by sick teachers, since most surplus teachers were reluctant "to be moved from one school to another". Contrary to the findings, the literature does not confirm that the placement of surplus educators in schools with shortages is a difficult exercise (Buchel 2006:14).

The majority of the participants recommended that the Department of Education should allow schools to reappoint retired teachers in order to address the problem of teacher shortage in their schools. This view concurs with that of Buchel (2006). It was also suggested that District Offices provide the schools with a list of retired teachers who are available to address teacher absenteeism in schools. All the participants were in agreement that schools had to develop school policies for the effective control of persistent absenteeism by HIV positive teachers. This aspect is outlined in the next section.

\section{Developing Appropriate Policies on HIV/AIDS, Sexual Abuse of Learners and Codes of Conduct}

Most participants indicated that their schools relied on school policies and the code of conduct to address the problem of persistent absenteeism by HIV positive teachers. Regarding their school's policy on HIV/AIDS, one principal explained:

As a school we have developed a functional HIV/AIDS policy after proper consultation with all role-players. This policy helps the school to reduce the impact of HIV/AIDS on educators and outlines the ways in which HIV/AIDS challenges can be addressed.

Another principal added:

Our HIV/AIDS policy makes provision for universal precautions, which assist the school to prevent the spread of all infections transmit- 
ted by blood, including HIV. Everybody is expected to comply with universal precautions to promote safety within the school, but the shortage of resources poses a serious problem.

In line with this comment, other participants expressed their concern about the shortage of First Aid Kits in their schools. They felt that the Department of Education should provide more First Aid Kits to schools so that each and every classroom has one. One principal remarked as follows: "If there is no First Aid Kit in the classroom, the educator will end up reporting an injury which could have been treated in the classroom". The provision of universal precautions at schools is in line with the literature, which states that the workplace environment must be healthy and safe to reduce the significant risk of HIV transmission (O'Connor et al. 2001: 60-61; Department of Education 2003: 29).

However, HIV/AIDS policies could not be effective unless teachers were informed about them. In this regard one principal remarked: "Unless HIV/AIDS policies are exposed to every staff member, the problem of absenteeism cannot be properly addressed". In line with this view, a teacher commented that "HIV/AIDS policies are only kept in files and are not visible to educators who are the victims of HIV/AIDS".

Participants were of the opinion that schoolbased gender violence required the necessary attention, since it could have a negative impact on the spreading of HIV/AIDS. They believed that especially high schools were "greatly affected" by sexual abuse. When participants were asked about the mechanisms to address the problem of sexual abuse of learners by teachers, they remarked that they had a code of conduct which was binding to all teachers. One principal explained:

We have also developed a policy that specifically deals with sexual relationships between educators and learners. For example, the policy spells out clearly that sexual relationships between educators and learners are forbidden, even if the learner consents, and iffound guilty, educators will be dismissed in terms of section 17 of the Employment of Educators Act 76 of 1998.

This view is in line with section 17.1c of the Employment of Educators Act 76 of 1998 that forbids any sexual relationship between teachers and learners in schools (Republic of South Africa 1998).
Concerning the prohibition of sexual relations of teachers with learners, one principal expressed her frustration by pointing out that doctors had to take an oath when entering their profession and enquired, "Why shouldn't we do it as educators"? She recommended that teachers entering the teaching profession should also take an oath "which is binding enough". According to her, this would assist principals in curbing gender violence and sexual abuse in schools. However, Buchel (2006: 10) doubts whether laws alone can solve the problem of school-based gender violence, since government officials have been turning a blind eye to this.

All the participants mentioned the importance of the development of school codes of conduct for learners and teachers which clearly stipulated all rules and regulations. One such rule mentioned was that sexual harassment must be reported to the principal and the South African Police Service. Buchel (2006) confirms that principals should create structures within which victims can complain without fear of retribution by perpetrators. According to the participants, the codes of conduct for learners and teachers in their schools had contained valuable information, such as toll free numbers, to report sexual abuse cases.

The majority of principals and teachers mentioned that they often invited the Department of Health, the Department of Social Welfare, the South African Police Service, the Employee Assistance Programme section and non-governmental organisations to their schools to raise awareness of the danger posed by HIV/AIDS. These participants also revealed that they also invited HIV positive people to address teachers and learners about their experience with HIV/ AIDS. They added that they found networking with departments other than the Department of Education really helpful in reducing HIV transmission in their schools, because it had always been aggravated by a lack of knowledge. The findings are in line with those of Simbayi et al. (2005) which state that collaboration with other government departments and non-governmental organisations is vital in reducing HIV transmission in schools.

The participants were in agreement that subject teachers who taught Life Orientation had to inform the other teachers and learners concerning the HIV/AIDS pandemic. One principal remarked: "Life Orientation educators must talk 
about the problems of HIV/AIDS to educators and learners every day". This principal warned that Life Orientation teachers should "not wait until something happens" and urged them to openly inform colleagues and learners about all the risks involved with unprotected sex, such as early pregnancy and sexually transmitted diseases. The literature also confirms that the presentation of the subject Life Orientation by teachers can greatly benefit HIV positive educators and learners (Simbayi et al. 2005; Helleve et al. 2011).

Another area of concern raised by the majority of participants was the inability of the Department of Education to punish offenders. Participants reported that although sexual abuse cases were correctly reported to the Employee Relations section of the Department of Education, investigations were delayed. One principal expressed her anguish as follows: "Once the accused educator suspects that the school is taking his case seriously, he will advise the learner to go to another school, which seriously cripples investigation". The literature has established that perpetrators of this crime of sexual relations with learners go unpunished and continue with their deeds (Buchel 2006; Leach 2002). It also confirms that this state of affairs creates the impression that gender violence is legitimate (Leach 2002).

Participants reported that poverty was playing a role in sexual abuse and violence. Rajagopaul (2008) confirms that poor socio-economic conditions are the main drivers of sexual abuse at schools. Parents were often tempted to accept bribes from accused teachers in exchange for remaining silent. The participants remarked that this problem was exacerbated by the fact that the South African Council for Educators was not adequately visible at schools with the result that disciplinary proceedings against offenders were seldom initiated. This finding is in line with that of Buchel (2006) that the government and the teaching fraternity stand accused of turning a blind eye to the perpetrators of sexual abuse cases in schools.

Considering the code of conduct for teachers, participants believed that it had to be "clearly communicated" to all teachers and that there had to be a more effective way of reporting when a teacher was going to be absent from school. All participants stressed the importance of monitoring the implementation of HIV/AIDS policies by all relevant role players, a point of view confirmed by Calitz et al. (2002) who believe that adequate HIV/AIDS policies will reduce the impact of HIV/AIDS on educators.

\section{Strengthening Schools as Centres of Care and Support}

When asked how schools ensured that care and support to HIV positive teachers were provided within their schools, the majority of principals pointed out that they utilised their schools as centres of care and support to render services to HIV positive teachers and vulnerable children. Moreover, one principal regarded it as their responsibility to create supportive environment to teachers infected by HIV/AIDS. She explained:

Principals should create an environment and a culture of non-discrimination within the school and encourage every staff member to be sympathetic and supportive towards HIV positive educators.

As part of the fight against HIV/AIDS, many participants maintained that their schools established Health Advisory Committees as a mechanism to manage and address HIV/AIDS related illnesses and "to strengthen their school as centres of care and support", as one principal noted. According to another principal, "having HACs [Health Advisory Committees] at school is extremely important as they draw attention to the health policy, organise campaigns against HIV/AIDS and refer HIV positive educators and learners to clinics and hospitals". Simbayi et al. (2005) confirm that the establishment of a Health Advisory Committee is vital and that it is also entrenched in the National Policy on HIV/AIDS. However, participants were of the opinion that HIV/AIDS policies did not properly address the problem of teacher absenteeism if many of the health problems experienced by HIV infected teachers were ignored.

Principals agreed that they usually encouraged their staff members to show love and support to teachers with HIV/AIDS. One principal remarked that teachers were often absent from school "because of the way they are discriminated against at the workplace" as a result of their HIV/AIDS status. To address this issue, another principal explained that their school had "a committee known as the Support Group" that ensured that all school policies were adequately 
implemented and that staff infected with HIV/ AIDS adequately supported.

The provision of food was a major form of support to teachers and learners alike that was identified by most participants. Participants mentioned that their schools had gardens to provide vegetables for teachers and learners infected with HIV/AIDS. One principal pointed out that she went a step further: "I normally share my lunch box with infected educators and send them messages in the afternoon to remind them about the taking of medication".

Most participants said that HIV positive teachers were encouraged to be involved in sports and that games against teachers from neighbouring schools were often arranged. In this way they were of the opinion that teachers would have less time to engage in unprotected sex and alcohol and drug abuse. Buchel (2006) too shows that school sport is an alternative to crime and, by implication, a positive factor in combating the spread of HIV/AIDS.

Some principals revealed that they invited motivational speakers such as pastors and lay counsellors to their schools to offer emotional and spiritual support to HIV positive teachers. One principal explained:

We ensure that HIV positive educators do have access to counselling services by inviting lay counsellors and psychologists to our school to assist HIV positive educators. My experience as a principal tells me that such programmes are important because they offer spiritual and psychological support and reduce stress to HIV positive educators.

Most principals and teachers argued that in the absence of a cure, more knowledge is required. One principal said: "Information is the most important weapon in the fight against HIV/ AIDS". Many principals pointed out that they had created a health and HIV/AIDS knowledge base in their schools and made it available and accessible to all teachers. According to participants, information was provided to teachers and learners in the form of illustrated books and posters on HIV/AIDS, education programmes, counselling programmes, workshops on HIV/AIDS and the teaching of the subject Life Orientation by guidance teachers. Calitz et al. (2002) confirm that sound health knowledge not only prevents educators and learners from irresponsible and potentially dangerous behaviour, but that it can also contribute to the maintenance of the best health possible in case of illness.
To manage the care and support system in his school, a principal explained:

The School Management Team, being supported by committees such as the Support Group and the school HIV/AIDS committees, monitor the implementation and effectiveness of these support systems. We also invite the departmental officials from the Circuit and District Offices when we experience problems regarding implementation [of policies to support infected staff].

The majority of the participants pointed out that HIV positive teachers were referred to the mentioned Employee Assistance Programme for counselling. Calitz et al. (2002: 164) endorse that timely counselling is vital and can serve as a lifeline for teachers who are affected by or infected with HIV/AIDS Participants also revealed that their schools relied on the services of Prevention, Care, Treatment and Access to deal with issues of HIV/AIDS, as confirmed by a report in The Citizen (Assistance for Aids-infected teachers 2005).

The participants were in agreement that they require more training sessions and workshops in order to meet the challenges presented to them by the HIV/AIDS pandemic among teachers and learners. One principal pointed out: "Training would provide us [principals] with knowledge and the necessary skills to manage educators with HIV/AIDS". To illustrate this point, a teacher mentioned that "principals who are not skilled in counselling may not necessarily be successful in supporting HIV positive educators". Other teachers were also in favour of more workshops saying that "they [workshops] would equip them with sufficient knowledge which could assist them [teachers] to disclose [their HIV/ADIS status] at an early stage".

All participants felt that training and workshops would finally address problems relating to HIV/AIDS stigma and discrimination, violation of confidentiality, prejudiced perceptions about HIV/AIDS and unfair labour practices such as dismissal of educators with HIV/AIDS in schools. O'Connor et al. (2001) support the idea of empowering HIV positive educators by informing them of their legal rights, as this knowledge can solve the problems they are experiencing in the workplace and ensure that they are treated fairly and sympathetically in terms of the Basic Conditions of the Employment Act.

The sampled participants were in favour of the development of school-based and commu- 
nity-based support systems to address HIV/ AIDS related problems, and commented that its success would depend on the support of all role players. Buchel (2006) also supports the distribution of condoms to community centres, but warns that care must be taken to avoid spreading the wrong message regarding the use of condoms.

Strengthening schools as support and caregiving centers implies its importance in dealing with individual teachers infected with HIV/AIDS.

\section{Strategies Dealing with the Disclosure of Information, Confidentiality and Dismissal of Teachers}

Concerning the disclosure of HIV/AIDS related information, the majority of participants agreed that disclosure of status was extremely important for the provision of quality care and treatment of infected individuals. One principal stated:

Disclosure of HIV status is crucial for provision of quality care and treatment. I usually show love and support to HIV positive educators to encourage disclosure.

Some principals revealed that they communicated informally about disclosure to their staff members by recording their talks on video tapes.

The majority of participants mentioned that their schools organised Life Skills programmes, invited lay counsellors, social workers and nurses and encouraged HIV positive teachers to reveal their HIV/AIDS status. They further remarked that they organised awareness campaigns in their schools and encouraged openness. Although the majority of participants supported the disclosure of status some principals admitted that at times they found it difficult to encourage the disclosure of HIV positive teachers since these teachers often displayed "anger and aggression". Moreover, the majority of participants admitted that it was becoming increasingly difficult for infected teachers to disclose their status because of the fear of losing their jobs. One principal stressed that HIV positive educators "must not sit with the problem until it is huge". These findings are consistent with the literature on disclosure of HIV/AIDS information which states that an environment and a culture of non-discrimination must be created where HIV positive teachers can be open about their HIV status (Department of Education 2003).
A principal argued that it was necessary that principals educated teachers about "what disclosure means". He said: "Do not listen and keep quiet after an educator has disclosed his or her status, but provide support such as encouraging them to take ARVs [Antiretroviral drugs]". Others, however, maintained that a person's HIV status was private and confidential and that disclosure was optional. One principal was of the opinion that confidentiality was the most difficult problem because a teacher "often disclosed his or her HIV/AIDS status" to the principal only to discover that he or she was "not the first one to receive that information". The Department of Education (2002) confirms that voluntary disclosure can be a powerful tool in preventing the spread of HIV, since infected employees can only receive support (such as counselling) if their HIV status is known to the employer.

All participants indicated that the nature of problems experienced by schools necessitated more HIV/AIDS training sessions and workshops.

\section{CONCLUSION}

The main purpose of this study was to identify strategies in schools to manage teachers with HIV/AIDS for the sake of developing mechanisms to address this problem more effectively. The transformation learning theory guided the "meaning-making process" of the study.

The study stressed the importance of putting different mechanisms in place in order to manage teachers with HIV/AIDS. Not only would the proper management of teachers with HIV/ AIDS improve the quality of life, it would also improve that of fellow teachers and learners. However, the adequate management of educators with HIV/AIDS can only be achieved through the participation of all the relevant role players.

\section{RECOMMENDATIONS}

In the light of the findings discussed above, it is possible to make a number of recommendations concerning the role of principals, teachers and the Department of Education in managing educators infected with HIV/AIDS. Principals have a duty to ensure that no class is ever without a teacher, to avoid the disruption of education. The careful monitoring of absenteeism pat- 
terns of teachers and a leave register depicting their absence kept as far as possible. Combining grades in schools should be refined and the timely appointment of substitute and qualified teachers should receive preference to combat teacher absenteeism. Principals' role also includes the encouragement of sick teachers to submit their applications for lengthy sick leave in advance, persuading staff to disclose their HIV/AIDS status for the sake of effective treatment and applying for membership of Medical Aid institutions to accelerate up the process of medical treatment as well as the application for sick leave. School principals can play a vital role in developing functional HIV/AIDS policies viewed in relation to policies on drug and alcohol abuse and sexual abuse; introducing codes of conduct pertaining to the control of persistent absenteeism by HIV positive teachers and ensuring their effective implementation of these policies and codes of conduct; establishing Health Advisory Committees to help fight against HIV/AIDS at schools; and liaising with the Department of Education to obtain the necessary resources to support HIV/AIDS infected teachers and to protect them against discrimination.

It is recommended that the Department of Education should set aside adequate funds for appointing substitute, qualified educators in schools, including retired, experienced teachers to alleviate the further shortage of professionally qualified educators resulting from the absence of teachers with HIV/AIDS. The Department to Education should address investigations of sexual abuse cases and offenders more speedily and should collaborate with with other state departments such as the Department of Health, the Department Social Welfare and non-governmental organisations to prevent new HIV infections and to support HIV positive teachers. It should provide more workshops to ensure that principals and teachers are provided with the necessary knowledge on the danger imposed by HIV/AIDS in schools.

HIV positive teachers are advised to disclose their HIV status as soon as possible to expedite quality care and treatment. They also need to be informed regarding their legal rights to avoid illegal and unconstitutional dismissals. Teachers have the responsibility to use the services of Prevention, Care, Treatment and Access which deal with issues of HIV/AIDS at schools. These services will enable them and their partners to check and understand their HIV/AIDS status and obtain the necessary treatment within the areas of their jurisdiction. Life Orientation teachers can play a huge role in conscientising educators and learners about the impact of the HIV/ AIDS pandemic on education provision.

\section{REFERENCES}

Anfare VA, Mertz NT 2006. Theoretical Frameworks in Qualitative Research. Thousand Oaks, CA: Sage. Assistance for AIDS-Infected Teachers 2005. The Citizen, April 7 2005, P. 9.

Badcock-Walters P, Kelly MJ, Gorgens M 2004. Does knowledge equal change? HIV/AIDS Education and Behaviour Change, January, 13: 4

Bogdan RC, Biklen SK 2007. Qualitative Research for Education: An Introduction to Theories and Methods. Boston: Pearson.

Buchel AJ 2006. The Leadership Role of the Principal in dealing with the Impact of HIV/AIDS in South African Schools. DEd Thesis, Unpublished. University of South Africa, Pretoria.

Calitz L, Fluglestad OL, Lillejord S 2002. Leadership in Education. Sandton: Heinemann.

Campbell C, Gibbs A 2008. Representations of HIV/ AIDS management in South African newspapers. African Journal of AIDS Research, 7(2): 195-208.

Changing Habits: The President and HIV Prevention 2010. The Witness, February 12, 2010, P. 10.

Coombe C 2000. HIV/AIDS and the Education Sector. The Foundations of a Control and Management Strategy in South Africa. Briefing Paper Commissioned by the United Nations Economic Commission for Africa.

Coombe C 2002. HIV/AIDS and education. Perspectives in Education, 20(2): 6-10.

Creswell JW 2007. Qualitative Inquiry of Research Design: Choosing among Five Approaches. London: Sage.

Creswell JW 2008. Educational Research: Planning, Conducting, and Evaluating Quantitative and Qualitative Research. Upper Saddle River: Sage.

Delport R, Strydom H, Theron L, Geyer S 2011. Voices of HIV and AIDS-affected educators: How they are psychosocially affected and how reds enabled their resilience. AIDS Care, 23(1): 121-126.

Department of Education 2000. The HIV/AIDS: Emergency Guidelines for Educators. Pretoria: Government Printers.

Department of Education 2002. Develop an HIV/AIDS Plan for your School: A Guide for School Governing Bodies, Management Teams, Managers and Educators. Pretoria: Government Printers.

Department of Education 2003. HIV and AIDS Life Skills Resource Guide for Educators. Republic of South Africa: Government Printers.

Erichson EA 2007. Transformative Learning Theory. From <http://uwstudentfpweb.uwyo.edu/E/ERICHSEN/Resource\%20Guide\%20Assignment.pdf $>$ (Retrieved March 10, 2009).

Firnhaber CS, Michelow P 2009. Clinical cervical cancer and the human immunodeficiency virus: A re- 
view. Southern African Journal of HIV Med, 10(2): 23-27.

Govender MS 2003. The Efficacy of the Department of Education's Response to HIV/AIDS in Changing Educators' and Learners' Risk Behaviours. DEd Thesis, Unpublished. University of South Africa, Pretoria.

Helleve A, Flisher AJ, Onya H, Mukoma W, Klepp K-I 2011. Can any teacher teach sexuality and HIV/ AIDS? Perspectives of South African Life Orientation teachers. Sex Education, 11(1): 13-26.

HIV and AIDS Statistics for South Africa 2010. From <www.avert.org/safricastats.htm> (Retrieved May $21,2010)$.

Kelly M. 2008. Gender, HIV/AIDS and the Status of Teachers. Maputo: Commonwealth Teacher Research Symposium.

Leach F 2002. School-based gender violence in Africa: A risk to adolescent sexual health. Perspectives in Education, 20(2): 99-112.

McLean M, Hiles L 2005. Introducing HIV and AIDS education into the first year of a problem-based learning curriculum: A template for health science education. Health SA/ Gesondheid SA, 10(2): 1723.

McMillan JH, Schumacher S 2010. Research in Education: Evidence-based Inquiry. Boston: Pearson Education.

Mezirow J 1995. Transformation theory of adult learning. In: MR Welton (Ed.): In Defense of the Life World: Critical Perspectives on Adult Learning. Albany: State University of New York Press, pp. 3970.

Mfusi BJ 2011. Needs and Challenges in Managing Educators with HIV/AIDS. MEd Dissertation, Unpublished. Pretoria: University of South Africa, Pretoria

Mkhonto CN 2005. The Management of an HIV/AIDS Awareness Programme in Secondary Schools in the North West Province. M Ed Dissertation, Unpublished. Pretoria: University of South Africa.

Mouton J 2009. How to Succeed in your Master's and Doctoral Studies: A South African Guide and Resource Book. Pretoria: Van Schalkwyk.

Neutens J, Rubinson L 2010. Research Techniques for the Health Sciences. New York: Pearson Education.

O'Connor S, Richter M, Wozniak A, Kraukamer R, Du Plessis L, Westcoot M 2001. Managing HIV/AIDS in the Workplace and Community: Positive People. Cape Town: Kagiso Education.
Rajagopaul V 2008. The Leadership Role of Primary School Principals in Economically Disadvantaged Areas Affected by HIV and AIDS. PhD Thesis, Unpublished. University of the Western Cape, Cape Town.

Rayners S 2007. The Leadership Role of Principals in Managing HIV and AIDS at Schools of the Western Cape Education Department. PhD Thesis, Unpublished. Cape Town: University of the Western Cape.

Republic of South Africa 1998. Employment of Educators Act, Act No 76 of 1998. Cape Town: Government Printers.

Republic of South Africa 1999. National Policy on HIV/ AIDS for Learners and Educators in Public Schools, and Students and Educators in Further Education and Training Institutions. Cape Town: Government Printers.

Republic of South Africa 2007. HIV/AIDS and STI Strategic Plan for South Africa 2007 - 2011. Cape Town: Government Printers.

Sawers L, Stillwaggon E 2010. Understanding the Southern African 'anomaly': Poverty, endemic disease and HIV. Development and Change, 41(2): 195-224

Shisana O Peltzer, K, Zungu-Dirwayi N, Lours JS 2005. The Health of Our Educators: A Focus on HIV/ AIDS in South African Public Schools. Cape Town: HSRC.

Simbayi LC, Skinner, D, Letlape, L, Zuma P 2005. Workplace Policies in Public Education: A Review Focusing on HIV/AIDS. Cape Town: HSRC.

The Stigma That Can Kill 2008. The Mercury, December 29, 2008, P. 7.

Theron L, Geyer S, Strydom H, Delport CSL 2008. The roots of reds: A rationale for the support of educators affected by the HIV/AIDS pandemic. Health SA/ Gesondheid SA, 13(4): 77-88.

UNAIDS 2006. Report on the Global AIDS Epidemic: Executive Summary, Joint United Nations Programme on HIV/AIDS (UNAIDS). Geneva: UNAIDS.

Van Wyk N, Lemmer E 2007. Redefining home-schoolcommunity partnerships in South Africa in the context of the HIV/AIDS pandemic. South African Journal of Education, 27(2): 301-316.

Visser MJ 2005. Life skills training as HIV/AIDS preventive strategy in secondary schools: Evaluation of a large-scale implementation process. Journal of Social Aspects of HIV/AIDS, 2(1): 203-216. 